\title{
A külföldi működő tőke által vezérelt iparfejlődési modell és határai Közép-Európában
}

\author{
The foreign direct investment driven industrial \\ development model and its limits in Central Europe
}

\author{
LUX GÁBOR
}

LUX Gábor: tudományos főmunkatárs, MTA Közgazdaság- és Regionális Tudományi Kutatóközpont, Regionális Kutatások Intézete; 7621 Pécs, Papnövelde u. 22.; lux@rkk.hu

KULCSSZAVAK: ipar; újraiparosítás; területi különbségek; posztszocializmus; külföldi működő tőke

ABSZTRAKT: A tanulmány célja az elmúlt évtizedekben meghatározóan a külföldi működő tőkére alapozott iparfejlődés összehasonlító értékelése a tágan értelmezett posztszocialista Közép-Európa országaiban és régióiban. Ez a folyamat, amely a rendszerváltások utáni dezindusztrializációt követően bontakozott ki, piaci erők által mozgatott, térben szelektív újraiparosodáshoz vezetett a posztszocialista országok régióinak egy részében. A külföldi működő tőkén alapuló iparfejlődés gyors megoldást kínált számos ipari térség válságára, és elősegítette Közép-Európa (újra)integrációját az európai, illetve a globális ipar munkamegosztásába. Bármennyire versenyképes struktúrák jöttek létre, az átalakulást nemcsak jelentős vállalatok közötti és térbeli különbségek fémjelzik, hanem ma már azt a kérdést is meg kell fogalmazni, hogy milyen mellékhatásokkal, haszonáldozati költségekkel járt a folyamat, és a következő évtizedekben mennyire marad fenntartható a jelenlegi növekedési modell. A tanulmány ezért öt részre oszlik. Az első részben megvizsgálja a gazdaságszerkezeti átalakulás Közép-Európa térszerkezetére gyakorolt következményeit, és azt, hogy milyen hajtóerők mozgatják az egyes gazdasági szektorok térbeli letelepülését. A második és harmadik részben bemutatja a külföldi működő tőkén alapuló iparfejlődés legfontosabb vonásait, valamint azt, hogyan lokalizálódnak az ipari tevékenységek, szakértői megkérdezés eredményeivel is alátámasztva. A negyedik rész a fejlődési modell buktatóiról, továbbfejleszthetőségének kérdéseiről szól, amit a tanulmány végén a közép-európai ipar fenntartható fejlődéséről megfogalmazott következtetések zárnak.

Gábor LUX: senior research fellow, Institute for Regional Studies, Centre for Economic and Regional Studies, Hungarian Academy of Sciences; Papnövelde u. 22., H-7621 Pécs, Hungary; lux@rkk.hu

KEYWORDS: industry; reindustrialization; regional differences; post-socialism; Foreign Direct Investment

ABSTRACT: This paper aims to provide a comparative assessment of the predominately Foreign Direct Investment (FDI)-driven industrial development model in post-socialist Central European countries

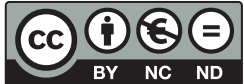


and regions. The development process, following post-transformational deindustrialization, has contributed to market-based, spatially selective reindustrialization trends in a number of postsocialist regions. FDI-based industrial development provided a rapid solution to the crisis of numerous industrial regions and encouraged Central Europe's (re-)integration into the European and global division of labor. Albeit the economic structures created by this process are rather competitive, restructuring, beyond showing prominent differences between firms and regions, also poses questions about the associated side-effects, opportunity costs, and about the FDI-driven model's long-term sustainability.

The paper is divided into five sections. The first examines the spatial consequences of Central Europe's economic restructuring, and the driving forces influencing different economic sectors' location behavior. In the second and third sections, the paper introduces the main features of FDI-driven industrial development and the way industrial activities become localized. This is also accompanied by the results of an expert survey. The fourth section discusses the pitfalls and the potential further enhancements of the development model, followed by the final section, which draws conclusions about Central European industry's sustainable development.

The paper argues that regional development should encourage the co-evolution of tertiary and industrial activities and focus more on the cultivation of flexible, adaptable industrial milieus rather than specific firms or even industrial branches. FDI will remain a long-term component of the macro-region's industrial competitiveness, but steps should be taken to empower mediumsized domestic companies to complement it. Finally, the key to successful development hinges on the long-term improvement of local factor supply and, in particular, on strong investment in human capital.

\section{A posztszocialista gazdaság térszerkezeti mintái: Az ipar továbbélő jelentőségéről}

Az 1980-as, 1990-es években a közép- és délkelet-európai országok ${ }^{1}$ kiterjedt és mély válság formájában szembesültek a mezőgazdaságból történő forráskivonáson, valamint a szolgáltató szektor tudatos visszaszorításán alapuló, a modernizációt az iparosítás és városfejlesztés kettősében látó államszocialista fejlesztéspolitika kudarcával. Nem csoda, hogy mind a rendszer általános kritikájában (Kornai 1980; Winiecki 1986), mind a rendszerváltások után megfogalmazott gazdasági programokban a fejlett és kiterjedt szolgáltató szektor létrehozása került előtérbe. Ez a szemléletváltás egyáltalán nem volt pusztán posztszocialista sajátosság: a posztindusztriális, tudásalapú gazdaság víziói a nyugati társadalmakban már korábban polgárjogot nyertek (Bell 1973; Miles 1993). A válságba jutott, a távol-keleti árversenyben lemaradó nagyvállalatok helyett egy kis- és középvállalkozásokra támaszkodó, karcsúbb és alkalmazkodóképesebb új ipar ideálképe rajzolódott ki, s jelentős várakozások fűződtek a gazdaság területi decentralizációjához (Harrison 1992; Horváth 1998). Az átalakulási folyamatok azonban mindkét esetben rácáfoltak az optimista elképzelésekre: a gazdaság szerkezeti átalakulása új, a korábbit meghaladó társadalmi és területi egyenlőtlenségek kialakulásához vezetett.

Az átalakulás tehát egyszerre volt posztszocialista és posztindusztriális (posztfordista). Az ipar és a gazdasági tervezés szerepe egyszerre értékelődött 
le; a posztszocialista országok maguk számolták fel azt az intézmény- és eszközrendszert, amelyek egy stratégiai szemléletű iparpolitika alapjául szolgálhattak volna (Rugraff 2008). A meghatározóan piacvezérelt, gyenge és forráshiányos közpolitikai beavatkozással körített szerkezetváltással a szolgáltató szektor vált a foglalkoztatás és értéktermelés fó forrásává, és a globális tendenciákkal összhangban elsősorban a szolgáltatások szívták fel az ipar munkaerő-fölöslegét. 2004-ben öt, 2013-ban három romániai régió kivételével már mindenhol a tercier foglalkoztatás részaránya volt a legmagasabb. A poszttradicionális ruralizáció, vagyis a munkájukat elvesztő ipari alkalmazottak mezőgazdaságba való visszatérése elsősorban Délkelet-Európában jelentkezett az átmenet első évtizedében (Kovács 2003; Molnár 2010; Petrakos, Totev 2000), de ez a hatás nem bizonyult tartósnak, a visegrádi országokban pedig Lengyelország keleti része kivételével jelentősnek sem.

Az általános tercierizáció statisztikai jelensége azonban jelentős tartalmi és területi különbségeket takar. A szolgáltatások előretörésében egyszerre jelenik meg a „túliparosodott” államszocialista országok gazdaságszerkezetének korrekciója; a posztindusztriális gazdaság új tevékenységeinek elterjedéséhez kötődő modernizációs folyamat; valamint a destruktív dezindusztrializáció jelensége, amely esetben az ipar visszaesését nem a versenyképes szolgáltató szektor megerősödése, hanem a gazdasági tér funkcióvesztése, „kiürülése” követi. Bár a három jelenség „rétegzett”, a második kettőben erős térbeli különbségeket mutathatunk ki, amelyek országok között és szubnacionális szinten is megnyilvánulnak, és differenciált térszerkezetet eredményeznek (1. ábra). Egyrészt:

- A visegrádi országokban a dezindusztrializációs folyamatokat a külföldi müködő tóke beáramlása által ösztönzött újraiparosodási folyamatok is ellensúlyozták. A transzformációs visszaesés időtartama aránylag rövidebb volt, hatásai pedig mérsékeltebbnek bizonyultak.

- Szlovéniában az iparvállalatok és a bankrendszer magas hazai tulajdoni részesedésére és a magas hozzáadott értékű, már 1990 előtt nyugati piacokra orientált termelésre épülő fejlődési modell egészen a 2008-as új gazdasági válságig biztosította az ipar viszonylagos stabilitását.

- Délkelet-Európa, különösen a volt Jugoszlávia erősebb dezindusztrializációját a térség politikai problémái, de a korábbi iparfejlesztés elmaradott struktúrái is magyarázzák; a dezindusztrializációban megjelenő szerkezeti hatások igen mélyek, a következmények pedig súlyosak voltak.

Másrészt a gazdaságszerkezet átalakulása háromosztatú térszerkezet kialakulásához vezet a makrorégió országaiban: ${ }^{2}$

- A posztindusztriális gazdaságok kiépüléséből származó előnyök jelentősen koncentrálódnak a nagyvárosi térségekben, elsősorban a fővárosokban. Mint az 1. ábra szemlélteti, a közép-európai országok többségében a meghatározó fejlett üzleti szolgáltatások, vagyis az infokommunikációs tevékenységek és a pénzügyi, biztosítási tevékenységek (NACE J és K) 
1. ábra: A gazdasági szektorok térformáló hatása Közép- és Délkelet-Európában (2013)

The space-shaping role of economic sectors in Central and Southeast Europe (2013)

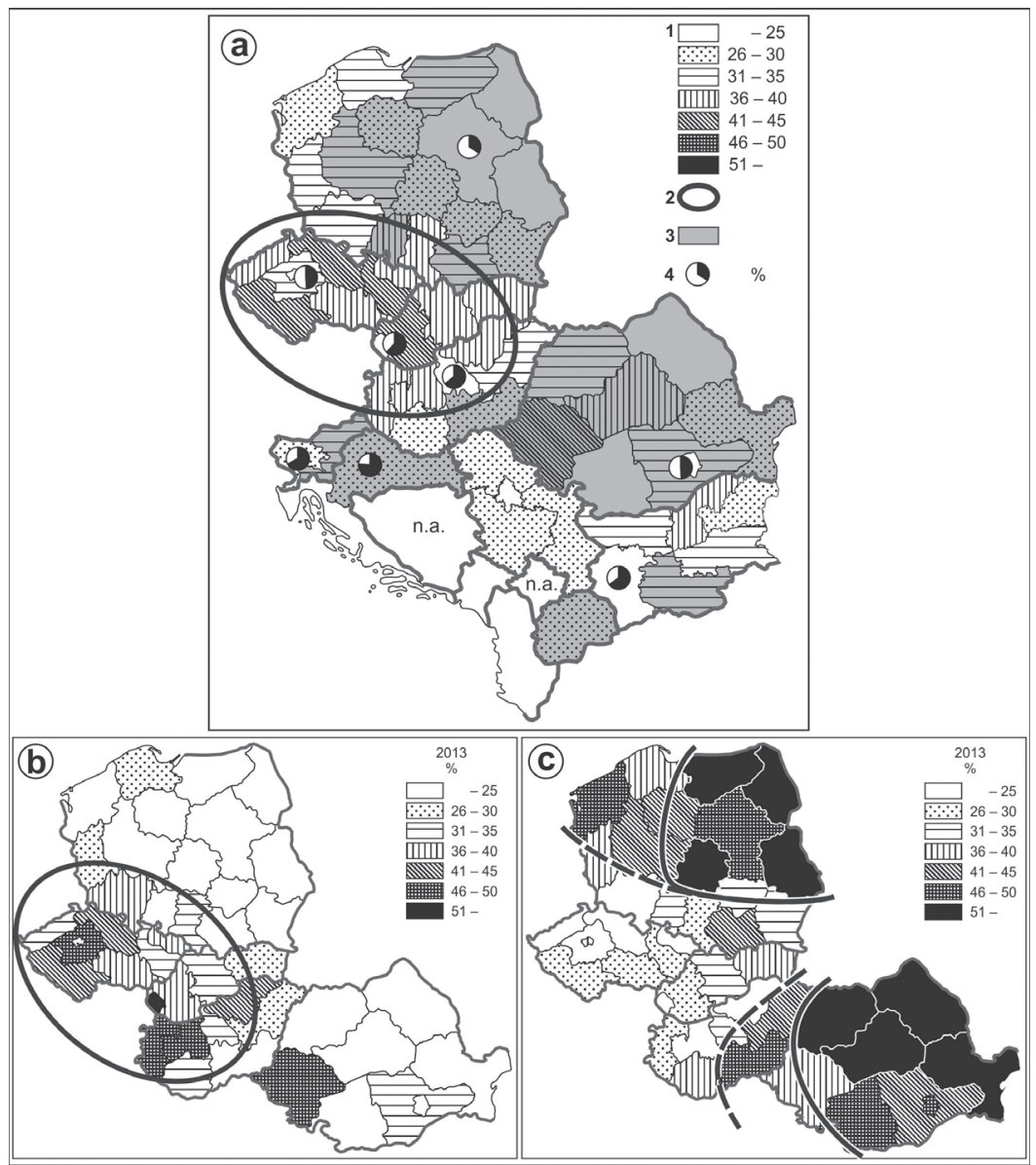

Jelmagyarázat: a) Szektorálisan kiemelt terek: 1 - az ipari foglalkoztatás aránya (\%), 2 - feldolgozóipari integrációs zóna, 3 - kiemelkedő agrárfoglalkoztatottsággal rendelkező régiók (>10\%), 4 - a fejlett üzleti szolgáltatások koncentrációja a központi régiókban (\%); b) A gépipar részaránya a teljes ipari foglalkoztatásban (\%); c) A könnyü- és élelmiszeripar részaránya a teljes ipari foglalkoztatásban (\%).

Forrás: az Eurostat adatai alapján a szerző számitásai és szerkesztése.

foglalkoztatásának több mint 60\%-a található a központi régiókban. ${ }^{3}$ Részleges kivételt a 49-49\%-os értékű Csehország és Románia, teljes kivételt pedig egyedül az erős ellenpólusvárosokkal rendelkező, policentrikus térszerkezetű Lengyelország képvisel. A központi régiókat a posztindusztriális gazdaságba történő sikeres beilleszkedés, a versenyképes szolgáltató szektor kiépülése jellemzi, még akkor is, ha pozícióik az európai, globális városhierarchiákban nem számítanak kiemelkedően erősnek (Csomós 2011). 
- A régiók második, átmeneti versenyképességi formát képviselő csoportját a külföldi működő tőke által vezérelt sikeres ipari átalakulás jellemzi. Ezek a régiók, amelyek ma a legmagasabb ipari foglalkoztatási aránnyal és a legkedvezőbb termelési értékekkel rendelkeznek Közép-Európában, egy többé-kevésbé összefüggő, a nyugati, főként német, osztrák és északolasz termelési rendszerekhez kapcsolódó feldolgozóipari integrációs zónát alkotnak Csehország, Délnyugat-Lengyelország, Kelet-Szlovákia és a magyar Észak-Dunántúl régióiban. Versenyképességük elsősorban az ipari tevékenységeken alapul, amelyekhez mintegy "kiegészítésként” erősödő szolgáltató szektor társul; a feldolgozóipar igényei és az aránylag magas lakossági jövedelmek keltette fizetőképes kereslet hozzájárul e szféra fejlődéséhez is. Ugyanakkor egyre jobban szembesülnek a súlyosbodó munkaerőhiány és a közepes vagy alacsony hozzáadott értékü termelés csapdahelyzetéből kiutat jelentő ipari feljebb lépés (upgrading) nehézségeivel.

- A dezindusztrializáció gazdasági és társadalmi költségei, az ipar leépülésének kedvezőtlen következményei aránytalanul felülreprezentáltak a periferikus régiókban, ahol a gazdasági tér „kiürülése”, a korábbi specializációk „utódok nélküli” felbomlása ment végbe. Ezek a folyamatok különösen érzékenyen érintették a munkaintenzív könnyü- és élelmiszeriparra specializálódó kisvárosokat és a vidéki térségeket, bár az előbbi iparágak gazdasági jelentősége továbbra is jól beazonosítható (1.c ábra). A mezőgazdaság foglalkoztató szerepe csak Romániában, Lengyelország keleti részén, és néhány elszórt régióban haladja csak meg a 10\%-ot, a teljes agrárvertikum regionális gazdasági szerepe ennél magasabb.

A dezindusztrializáció vagy tercierizáció megítélése tehát differenciált kell hogy legyen, mert összetett jelenségként egyszerre közvetíti az átalakulás pozitív és negatív hozadékát, és egyazon térségben is jelentős trade-off hatások, alternatív költségek érvényesülhetnek. Látható, hogy a három gazdasági szektor más-más térszerveződési mintát rajzol ki (1.a ábra): a szolgáltató szektor a meghatározó nagyvárosi csomópontok köré rendeződik; a legversenyképesebb iparágakban jelentős szerepet játszik egy összefüggő magtérség; a mezőgazdaság, valamint egyes hagyományos iparágak pedig a gazdasági perifériákon töltenek be az átlagnál nagyobb szerepet. ${ }^{4}$ Általában megfogalmazható következtetés, hogy az ipar és szolgáltatások eltérö mintái által tagolt tér sokszínübbé, differenciáltabbá vált, amelyben erősödő különbségekkel szembesülünk.

\section{A külföldi működő tőkén alapuló ipari integráció}

A posztszocializmus két évtizedében Közép-Európa a globális ipari relokációs folyamat nyertesévé vált, az ipar visszaesését 1995-től újraiparosodás követte 
(Barta, Czirfusz, Kukely 2008). A delokalizáció hátrányai sokkal mérsékeltebbek voltak (Kiss 2007b), még akkor is, ha egyes, föként kisvárosi térségekben, specifikus iparágakban ezeket a hatásokat sem lehet figyelmen kívül hagyni. ${ }^{5}$

A posztszocializmus piacvezérelt átalakulási folyamataiban egyszerre jelenik meg az örökölt struktúrák útfüggő fejlődése és a külföldi működő tőke térformáló hatása. Vitathatatlan, hogy az idő előrehaladtával az utóbbi tényező egyre nagyobb jelentőségre tesz szert, de a kedvező ipari örökség tényezői továbbra sem hagyhatók figyelmen kívül: a sikeres ipari átalakulás terei jellemzően korábbi ipari hagyományaik újraszervezésével, újraspecializáció révén alakították ki mai versenyképességi profiljukat. A külföldi működő tőke beáramlása jelentős „előre gyártott” versenyelőnyöket biztosít telephelyei számára: technológiatranszfert, a modern menedzsment- és minőségbiztosítási elvek meghonosodását, könnyen elérhető csatornákat a globális piacokra, valamint a hazai tulajdonú vállalatok által elérhetetlen tőkefinanszírozási lehetőségeket. A globális értékláncokba illeszkedő helyi szereplők számára ez az integrációs pálya magas versenyképességet biztosított környezetük versenytársaival szemben, bár, mint Humphrey és Schmitz (2002) jelzi, egyszerre hordozza a túlspecializáció és az alacsony beágyazottság kockázatait.

A másik oldalon, a vállalati léptéken túllépve, a külföldi működő tőkén alapuló fejlődés sikertörténetei sem a „semmiből” bontakoznak ki, és cseppet sem függetlenek a gazdasági tér hosszú távú átalakulási folyamataitól. A beruházók bőségesen merítettek a lokális, regionális piacok termelési hagyományaiból és lokalizált versenyelőnyeiből, újrakonfigurálva termelési tényezőiket, tudáskészletüket és a mögöttük álló intézményeket illetve társadalmi-gazdasági hálózatokat. A hazai vállalatok „visszavonulása” először fellazította a termelési rendszereket, majd új konfigurációk kiemelkedésére adott lehetőséget. Ez a fejlődés útfüggő oldala, amely nem függetleníthető az ipari térségek evolúciós fejlődési pályáitól. Ahol az avatatlan szemlélő véletlen eseményeket lát, ott a gazdaságtörténész előképek gazdag tárházát. ${ }^{6}$ Ezekben az esetekben az alternatívákról és haszonáldozati költségekről (kihagyott lehetőségekről) is jogos, sőt szükséges beszélni.

A külföldi működő tőke által vezérelt fejlődés vállalati és területi különbségei, a duális ipar kialakulása régóta téma az ipari kutatásokban (Barta 2005; Havlik 2005; Kiss 2007a). A sokkal jobb tőkeellátottsággal, technológiai és piaci ismeretekkel, exportképességgel stb. rendelkező külföldi vállalatok térformáló képessége is messze maga mögé utasítja helyi versenytársaikét; telephelyválasztásuk pedig a területi különbségek emelkedése felé mutat (ez alól egyedül az endogén fejlődési jegyeket mutató Szlovénia kivétel). Egyértelmű és erős összefüggés mutatkozik a külföldi működő tőke beáramlása és a gazdasági teljesítmény között. Barta (2000) adatai szerint 1997-ben Magyarországon 33\%-os volt a külföldi működő tőke aránya a GDP elő́llításában; Nölke és Vliegenthart (2009) adatai szerint 2007-ben a külföldi tulajdonú vállalatok Magyarországon már a GDP 52\%-át, Csehországban 48\%-át, Szlovákiában 32\%-át, Lengyelország- 
ban pedig 25\%-át állították elő. Ezekkel az adatokkal a térség országai jócskán megelőzik a fejlett gazdaságok többségét (így pl. Ausztria értéke 23\%, Németországé csak 16\%). Az EU iparszerkezeti jelentése (Competing in global value chains 2013) szerint az unión belül Szlovákia, Magyarország és Csehország ipara integrálódott legmélyebben a globális értékláncokba, és ez az állítás a fó iparágakra (elektronikai és optikai ipar, gépipar) külön-külön is megáll. Lengyelország valamennyire kivétel, amit részben robusztus belső piacának, részben pedig aránylag erős hazai középvállalatainak köszönhet. A jelentés azt is kiemeli, hogy az „új tagállamokban” a bruttó ipari export nagyon magas importtartalommal (vagyis alacsony helyi hozzáadott értékkel) rendelkezett: 2009-ben Magyarországon $52 \%$, Csehországban 44\%, Szlovákiában 40\%, Lengyelországban $33 \%$.

A különbségek térben is markánsan kitapinthatók. Ahogy az előző részben láthattuk, a külföldi működő tőkén alapuló ipar (legyen szó beruházásokról vagy foglalkoztatásról) nagyja a feldolgozóipar fö integrációs zónájában összpontosul, s történelmi fejlődési pályák, tőkefelhalmozási folyamatok által is befolyásolt (Enyedi 1978). A térszerveződés azonban iparáganként eltérő; másként érinti a főként az integrációs zónában megtelepült, erős külföldi működőtőke-hányaddal rendelkező gépipart, és másként a perifériákon még mindig erős könnyű- és élelmiszeripart (1.b és 1.c ábra). Ez a két mintázat a területi fejlődés eltérő formáit képviseli. Az első esetben a globális értékláncok, s különösen az 1990 előtti jármüipari központokat is revitalizáló autóipar integráló ereje meghatározó, s ezen belül is a német autógyártóké, amelyek egy minden termelési és szolgáltató funkciót magában foglaló „teljes tér” létrehozására törekedtek a szélesebben értelmezett Közép-Európában (Frigant, Layan 2009; Krzywdzinski 2014; Molnár 2012; Pavlínek, Domański, Guzik 2009; Wójtowicz, Rachwał 2014).

Valamivel kevésbé látványos, de kitapintható a keleti és délkeleti perifériákon lezajló ipari újraszerveződés. Amellett, hogy ezeket a régiókat mélyebben érintették a dezindusztrializáció kedvezőtlen hatásai, szintén jellemző rájuk a nemzetköziesedés, amely a (föként lengyel) élelmiszeripar, valamint a (föként délkelet-európai) textilipar útkereséséhez kapcsolódnak. A textilipar esetén súlyos problémát jelent a globális értékláncokban elfoglalt alacsony pozíció, amelyekből a helyi termelők többnyire nem tudtak kitörni (Anić, Rajh, Teodorović 2008; Evgeniev 2008; Yoruk 2004). Délkelet-Európa országaiban a nyugat-európai, amerikai és távol-keleti tőkebefektetők helyett gyakran török és görög kisés középvállalatok a beruházók. Kisebb méretükön túl (Kaditi 3600 görög tőkeexportőr KKV-t említ) jellemző rájuk, hogy inkább az alacsony és közepes technológiájú, munkaintenzív iparágakban jelentek meg, de magasabb technológiai és kulturális közelségük révén jobban beilleszkednek környezetükbe és erősebb tudásbeli spillovereket generálnak, mint a fejlettebb, de gyakran szigetszerü nyugati beruházási projektek (Kaditi 2013; Monastiriotis, Alegria 2011; Totev 2005). Ugyanakkor a 2005-2008 között tetőző, évi 1500-ról 5200 millió euróra emelkedő görög tőkeexport üteme megtört, majd az ország elmélyülő válságával 
2013-ra tőkekivonásba torkollott. Ha hozzátesszük a görög hitelintézetek szerepét Délkelet-Európa bankszektorában, könnyen előrevetíthetjük az iparra váró kedvezőtlen következményeket is.

\section{Az ipari versenyképesség lokalizációja}

Az iparfejlesztés a mai értelmezésében elsősorban helyi fejlesztés; egy város, városi térség, iparági körzet vagy régió szisztematikus fejlesztése. A térérzéketlen fejlesztési gyakorlat korábbi kudarcai bebizonyították, hogy az ipar helyi kontextustól független fejlesztése rossz hatékonyságú, fenntarthatatlan struktúrákat eredményez. ${ }^{7}$ A környezetüktől elkülönülten müködő, alacsony versenyképességü, általában erős külső függésben élő vállalatok, vállalati részlegek kiugróan érzékenynek bizonyultak a külső megrázkódtatásokkal, tőkekivonással szemben. A globális-lokális paradoxon; a globális versenyben élő modern gazdasági tevékenységek, versenyelőnyök erős lokalizációja, térhez kötöttsége (Lengyel 2010) meghatározóvá teszi a helyi környezet jelentőségét. A posztfordista ipar versenyképességében a méretgazdaságosság mellett egyre inkább a térhez kötődő agglomerációs előnyök és különböző externáliák biztosítják a termelők versenyelőnyeit (Bailey, De Propris 2014). A fejlesztés gyakorlatilag lokalizált erőforrás-koncentrációt jelent; egyre kevésbé konkrét ipartelepítést, és egyre inkább az értékes ipari beruházásokat vagy a helyi ipar endogén fejlödését ösztönző keretfeltételek, a gazdasági és társadalmi környezet fejlesztését. A kiemelkedően sikeres gazdasági terek jobbára olyan koncentrációk, amelyek erős belső kapcsolatrendszerrel, valamint tematikus és térben kijelölt határokkal rendelkeznek; a globális gazdaság szövetébe ágyazódva, de megkülönböztetve magukat környezetüktől (Menzel, Fornahl 2009). A föáramú fejlesztéspolitika megközelítései és eszközei - klaszterek, regionális innovációs rendszerek, iparági körzetek, fejlesztési pólusok stb. - többnyire maguk is ezt a szemléletet képviselik (Egyed 2014; Faragó, Lux 2014).

Az egyedi versenyképességi tényezők helyett azok csomagjaira, helyspecifikus kombinációira alapozott lokalizált versenyképesség az endogén fejlődés ideája felé mutat, de - mint az iparági körzetek példája is mutatja - előnyeit a külső (külföldi működő tőkén alapuló, a globális értékláncokba ágyazódott) szereplők is előszeretettel használják, lefölözik. Ez egyben arra is utal, hogy az iparcentrikus helyi gazdaságfejlesztés nem jelent feltétlenül értékválasztást a külföldi tőke és a hazai tulajdon között: egy szintig könnyü megtalálni a közös érdekeket, komplementeritásokat.

A napjainkban egyre fontosabb lokalizált versenyképesség terén azonban a közép-európai ipar máig tartó gyengeségeket örökölt, amelynek forrása részben a történelmi alulfejlettség, részben pedig az államszocializmus öröksége, amely vertikális fejlesztési logikája révén felszámolta a horizontális társadalmi 
és gazdasági hálózatokat. Ezt a kedvezőtlen örökséget tovább tetézte a destruktív dezindusztrializáció és a posztszocialista perifériák kiürülése (funkcióvesztése, homogénné válása), s problémáira a külföldi működő tőkén alapuló fejlődés sem kínál gyógyírt. Miközben a betelepülő iparvállalatok a köztük és környezetük között húzódó technológiai rés, esetleg tevékenységeik alacsony hozzáadott értéke miatt gyakran igen csekély területi integrációs potenciált mutatnak, a hazai ipar esetén a probléma forrása a kis üzemméret, a gyenge tényezőellátottság és az elégtelen hálózati sűrüség. Bár korábbi kutatások Magyarországon rámutattak a hazai tulajdonú középvállalatok helyi gazdaságfejlesztésben és fejlesztési koalíciók kialakításában betöltött jelentőségére (Lux 2013), ezt a bármennyire biztató jelenséget sajnos nem hasonlíthatjuk össze a nyugat-európai ipari hálózatok sok évtizedes, évszázados töretlen fejlődésével.

A lokalizált versenyelőnyök térben differenciált „ökoszisztémájának” újjáépítése tehát erőt próbáló feladat, s az eddigi eredmények igen szerények. A megújuló versenyprofilok kialakulására azok az ipari térségek szolgáltatják a legjobb példát, ahol az útfüggő termelési hagyományok és a külföldi tőke kombinációja, kisebb mértékben néhány hazai közép- és nagyvállalat sikeresen mentett át egy meglévő tudáskészletet, s indított el az iparon kívül a helyi tudásbázist és intézményrendszert is átformáló pozitív akkumulációs folyamatokat. ${ }^{8}$ Ez a kör a kilencvenes évek pesszimista jóslatai ellenére több egykori válságövezetet, régi ipari térséget is érint: a várakozásokkal ellentétben a nehézipar egykori fellegvárai gyakran meglepő regionális rugalmasságot mutattak, hatékonyan találták fel magukat az új versenykörnyezetben (Baranyai, Lux 2014; Drobniak, Kolka, Skowronski 2012; Gwosdz 2014; Páger 2013; Pástor, Šipikal, Rehák 2013; Sucháček et al. 2012). Kisebb léptékü sikertörténeteket máshol is találunk, például egyes élelmiszeripari vagy könnyüipari központok adaptációjában (Molnár, Lengyel 2015). Úgy tűnik, a siker legtöbbször az örökölt képességek megőrzésén és fokozatos átalakításán múlik, s nem a radikális szerkezetátalakítás vízióin. Sokkal ritkább jelenség, hogy egy ipari térség a „semmiből” vagy a destruktív dezindusztrializáció kiteljesedését követően önállóan teremtsen új fejlődési pályákat. Fejlesztési projektek sorának megbicsaklása mutatja, hogy az innovatív, magas hozzáadott értékủ iparágak meghonosítása milyen nehézségekkel küzd a periférián, s hogyan véreznek el vagy maradnak csökevényesek elégtelen kritikus tömegük, az őket körülvevő hálózatok alulfejlettsége vagy alapvető tőkefinanszírozási problémák következményeként. ${ }^{9}$ Persze a perifériákon is találni sikeres, mozgékony, versenyképes iparvállalatokat: ezek azonban egyedi kivételek komolyabb tovagyürüző hatások nélkül, és kevésbé egy eljövendő sikerszéria kedvező előjelei. A perifériák újraiparosítása sokkal összetettebb és nehezebb feladat, mint a meglévő képességek és növekedési tényezők átalakítása, új formákba öntése.

A tanulmány elkészítését is támogató kutatásban közép-európai területfejlesztési szakembereket kérdeztünk (többek között) a helyi ipartelepítési tényezőkről (1. táblázat). ${ }^{10} \mathrm{Az}$ itt feltett kérdésekre érkezett válaszok száma (n) 90 és 101 
1. táblázat: Ipartelepítési tényezők szakértői értékelése Közép-Európában Expert evaluation of industrial location factors in Central Europe

\begin{tabular}{|c|c|c|c|c|c|c|c|c|}
\hline \multicolumn{3}{|c|}{ A jelenlegi telepitési tényezók értékelése } & \multicolumn{6}{|c|}{ A telepitési tényezők fejlesztési prioritásai } \\
\hline Tényező megnevezése & $\begin{array}{c}\text { Skála } \\
1-5\end{array}$ & $n$ & $\begin{array}{l}\text { 1. hely } \\
n=99\end{array}$ & $\begin{array}{l}\text { 2. hely } \\
n=97\end{array}$ & $\begin{array}{l}\text { 3. hely } \\
n=90\end{array}$ & $\begin{array}{l}\text { 4. hely } \\
n=78\end{array}$ & $\begin{array}{l}\text { 5. hely } \\
n=70\end{array}$ & $\begin{array}{c}\text { Átlag } \\
\%\end{array}$ \\
\hline Makrogazdasági feltételek & 3,2 & 100 & 14 & 4 & 7 & 5 & 6 & 8 \\
\hline $\begin{array}{l}\text { Adókedvezmények és egyéb támo- } \\
\text { gatások }\end{array}$ & 3,0 & 99 & 16 & 10 & 3 & 11 & 3 & 10 \\
\hline $\begin{array}{l}\text { Színvonalas üzleti szolgáltatások } \\
\text { elérhetősége }\end{array}$ & 3,2 & 100 & 8 & 8 & 6 & 7 & 6 & 8 \\
\hline $\begin{array}{l}\text { Közúti elérhetőség, logisztikai } \\
\text { adottságok }\end{array}$ & 3,5 & 99 & 15 & 11 & 8 & 4 & 1 & 9 \\
\hline $\begin{array}{l}\text { Légi elérhetőség, repülőtéri logisz- } \\
\text { tika }\end{array}$ & 3,3 & 100 & 5 & 10 & 5 & 2 & 5 & 6 \\
\hline $\begin{array}{l}\text { Földrajzi elhelyezkedés, piacok } \\
\text { elérhetősége }\end{array}$ & 4,0 & 101 & 1 & 0 & 4 & 1 & 4 & 2 \\
\hline Mérsékelt munkaerőköltségek & 3,5 & 99 & 0 & 7 & 3 & 5 & 5 & 5 \\
\hline Képzett munkaerő, ipari know-how & 3,6 & 98 & 9 & 10 & 12 & 4 & 4 & 9 \\
\hline $\begin{array}{l}\text { Rugalmasság, alkalmazkodóképes- } \\
\text { ség, megbízhatóság }\end{array}$ & 3,3 & 99 & 10 & 8 & 11 & 6 & 6 & 9 \\
\hline Innovációs háttér, $\mathrm{K}+\mathrm{F}$, felsőoktatás & 3,4 & 100 & 12 & 20 & 12 & 14 & 2 & 14 \\
\hline $\begin{array}{l}\text { Intézményi háttér, partnerség, üz- } \\
\text { leti támogató intézmények }\end{array}$ & 3,2 & 99 & 8 & 7 & 12 & 13 & 11 & 12 \\
\hline $\begin{array}{l}\text { Iparági körzetek, klaszterek, ipari } \\
\text { parkok közelsége }\end{array}$ & 3,4 & 98 & 1 & 2 & 4 & 4 & 10 & 5 \\
\hline Egyéb, városokhoz kötődő előnyök & 3,6 & 90 & 0 & 0 & 3 & 2 & 7 & 3 \\
\hline
\end{tabular}

Forrás: online kérdőíves felmérés alapján a szerző számitásai és szerkesztése.

közé esett, amely alkalmas összegzésre, de a válaszok országos vagy mélyebb szintủ lebontására nem. A válaszadókat először arra kértük, hogy 1 (nagyon gyenge) és 5 (nagyon erős) közötti skálán értékeljék közép- és kelet-európai kontextusban régiójuk ipartelepítési tényezőit. Ezt követően arra kértük őket, hogy egy előre felállított listából válasszák ki és rangsorolják azt az ötöt, amelyek fejlesztését a legfontosabbnak tartják régiójuk versenyképességének növelése érdekében.

Az első kérdésre adott válaszok nem okoztak nagy meglepetést 3,4-es átlagukkal, s a válaszadók ezen belül kedvezőbben értékelték régiójuk földrajzi elhelyezkedését és a piacok elérését, míg legkevésbé az adókedvezmények és támogatások elérhetőségével, a színvonalas üzleti szolgáltatásokkal, valamint az intézményi háttértényezőkkel voltak elégedettek. Ennél érdekesebb a második kérdés: a válaszokból kiviláglik, hogy a megkérdezett szakemberek az innovációt tartották a legfontosabb fejlesztési szükségletnek, amelyet a háttérintézmények, valamint az adókedvezmények és támogatások követtek. Szembetűnő, hogy az első helyekre az általános (országos szintű, jobbára térsemleges) tényezők kerültek, s ez alól csak a közúti elérhetőség jelent kivételt. Közvetlenül az 
általános ipartelepítési tényezők mögött (vagyis már a második-harmadik helyen) azonban lokalizált, helyben gyökerező tényezőket is találunk: ilyen az innováció, a képzett munkaerő, a rugalmasság és alkalmazkodási készség vagy éppen a helyi intézményrendszer. Bár a telepítési tényezők mindkét csoportja lényeges, az első csoport jobban reprezentálja a jelenlegi közép-európai fejlődési modellt, míg a második csoport ebben és a következő évtizedben válik majd egyre lényegesebbé. A térben differenciált versenyképesség, az ipari feljebb lépés eltérő helyi megjelenési formái egyre növekvő jelentőségre tesznek szert, s a belülről, helyben fakadó fejlődési képesség dönt majd arról, mely térségek lesznek a poszttranzíciós időszak új nyertesei.

\section{A külföldi müködő tőkén alapuló fejlődési út határai}

A versenyképes ipari tevékenységek letelepedése a globális ipari integráció legkönnyebben megfogható sikerkritériuma, de a valóban örömteli eredményeket már a versenyképesség fenntarthatósága, az alkalmazkodási képesség (rugalmasság) és a feljebb lépési teljesítmény jelenti. A termelés tényezőintenzitása és a közép-európai ipar globális munkamegosztásban elfoglalt helye egyben azt is kijelöli, hogy milyen minőségü ipar jellemzi a közép-európai ipari térségeket - és mindez hogyan járul hozzá a széles körben elérhető jólét, a társadalmi célok eléréséhez.

A posztszocialista átalakulás első éveiben a munkaintenzív termelés vált az európai (újra)integráció legegyszerűbb formájává, miközben az értékesebb, magas specializációt mutató vagy kedvező tudástartalmú ipari funkciók gyakran leépültek, s csökkent az ipari termelés amúgy sem túl erős területi beágyazottsága. Az ezredfordulóra azonban az új külföldi működőtőke-beruházások és az ipari feljebb lépés hatására egy stabilabb, jellemzően skálaintenzív vagy szakosodott ellátó, ritkán korlátozott tudásintenzív funkciókat is megjelenítő integrációs modell vált meghatározóvá a feldolgozóipari integrációs zóna tereiben (Jürgens, Krzywdzinski 2009; Lefilleur 2008; Pavlínek 2012). A feldolgozóipari vállalatok zöme közepes technológiai színvonalú és közepes hozzáadott értékű termékeket állít elő közepes képzettségű munkaerővel. Ami hiányzik ebből a kétségtelenül jól működő modellből, az egyrészt az értéklánc legértékesebb része (az irányítási, $\mathrm{K}+\mathrm{F}-$, design- stb. funkciók és a kapcsolódó fejlett üzleti szolgáltatások), másrészt az alacsony képzettségü munkavállalók - Nyugat-Európában úgy-ahogy még megvalósuló -, szociális célokat is szolgáló foglalkoztatása. ${ }^{11}$ Közép-Európában a feljebb lépés és a változó versenykörnyezet erős nyomást gyakorol az előbbi körön kívüli ipar szereplőire is, és fokozatosan „kiárazza” a piacról az alacsony hozzáadott értékü tevékenységeket (Pavlínek, Ženka 2010). Ez a jelenség jól érzékelhető a makrorégió nyugati integrációjának elmélyülésével, amely már nem írható le egyszerủ centrum-periféria viszonyként, hanem a kölcsönös, bár 
cseppet sem egyenlő felek közötti függőség határozza meg. A versenyképes iparágakban megvalósul a fokozatos feljebb lépés, a tényezőintenzitás lassú növekedése, miközben a (Lengyelországon kívül jobbára persze szintén külföldi tulajdonú) beszállítói hálózatok is erősödő területi integrációt mutatnak.

Az új gazdasági válság nem rendítette meg a külföldi működő tőke vezérelte fejlődési pályát. Bár az exportorientált iparágak rövid távon a gazdasági sokk veszteseivé váltak, amelyre gyors leépítésekkel és termelésük visszafogásával reagáltak, ezt a kivitel gyors helyreállása követte. Ezzel szemben a belső kereslet szűkülése (Lengyelországot kivéve, ahol a nagy és stabil belső piac előnyei enyhítették a válságjelenségeket) tartós, közepesen erős negatív hatást gyakorolt az ipar fejlődési kilátásaira (Barta, Lőcsei 2011; Lengyel 2014). Az elhúzódó válság időszakában, bár a korábbinál lassabb ütemben, de folytatódott a külföldi tőke beáramlása és az ipar nemzetköziesedése; Lengyel adatai szerint a magyar feldolgozóiparban 2008 és 2011 között a bruttó hozzáadott érték 62\%-áról 73\%-ára emelkedett a külföldi tulajdon részesedése. A gazdaság szerkezeti átalakulását a régiók többségében a lassú ütemű, de kitartó, piacvezérelt újraiparosodás jellemezte, amely alól 2004 és 2008 között Magyarország, Szlovénia, és Románia egyes régiói, 2008 és 2013 között pedig a déli, délkeleti lengyel régiók csoportja jelentett kivételt (2. ábra).

Ezzel párhuzamosan a térség államai az Európa-szerte sikeresnek tartott német modellt követve az iparnak kedvező szerkezeti reformok sorát vezették be, így pl. a duális szakképzési rendszer meghonosításával (Magyarországon és Romániában; Csehországban és Szlovákiában már korábban is ez a gyakorlat

2. ábra: Az ipari foglalkoztatás alakulása az EU-csatlakozás és a válság időszakában (\%) Industrial employment in the accession period and the crisis (\%)

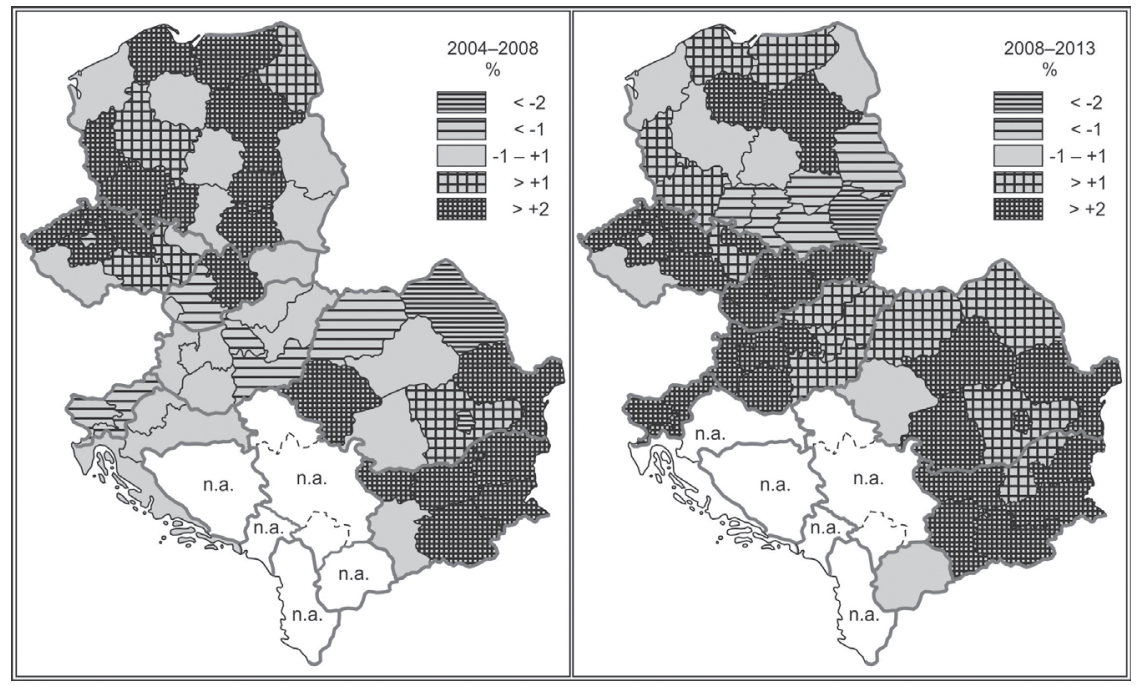

Forrás: az Eurostat adatai alapján a szerző számításai és szerkesztése. 
működött), vagy az innovációtranszfert ösztönző támogatások és intézmények megerősítésével (Csehország és Lengyelország). Az ezekben az években született újraiparosítási stratégiák - amelyeket Magyarországon támogatói és ellenzői is előszeretettel tartanak valamiféle bogaras különutasság megnyilvánulásának - valójában az egész EU-ban (sőt, a korábban főként „implicit” vagy „rejtett” iparpolitikával él” Egyesült Államokban is) ismét polgárjogot nyert új iparpolitika közösségi célkitüzéseit és eszközeit követő koncepciókból táplálkoznak (A stronger European industry for growth and economic recovery 2012; For a European industrial renaissance 2014). A nemzeti stratégiák, ahogy más területeken is, gyakran apró részleteikben is megegyeznek az uniós dokumentumokkal, kitűzött céljaik pedig (mint pl. az ipar részesedésének 30\%-osra emelése a bruttó hozzáadott érték előállításában Magyarországon) - Lengyellel és szerzőtársaival (2016) egyetértve - ambiciózusak, de nem elérhetetlenek. Az uniós célérték 2020-ra 20\% volt; Németország mellett Csehország, Szlovénia és Magyarország már 2014-ben is megfelelt ennek az elvárásnak, de Litvánia, Szlovákia, Lengyelország és Észtország sem állt távol tőle (3. ábra). Ezzel együtt is valószínűbb, hogy az újraiparosodási folyamatok - multiplikátor-hatásaikon keresztül - végső soron a gazdaságszerkezet további tercierizációja felé mutatnak majd, részben a fogyasztás emelkedésén keresztül, részben az üzleti szolgáltatások (térben mégolyan egyenlőtlen) fejlődésével.

3.ábra: A feldolgozóipar aránya az EU-tagállamok bruttó hozzáadott értékében (2014,\%)

The proportion of manufacturing in the EU member countries' Gross Value Added (2014, \%)

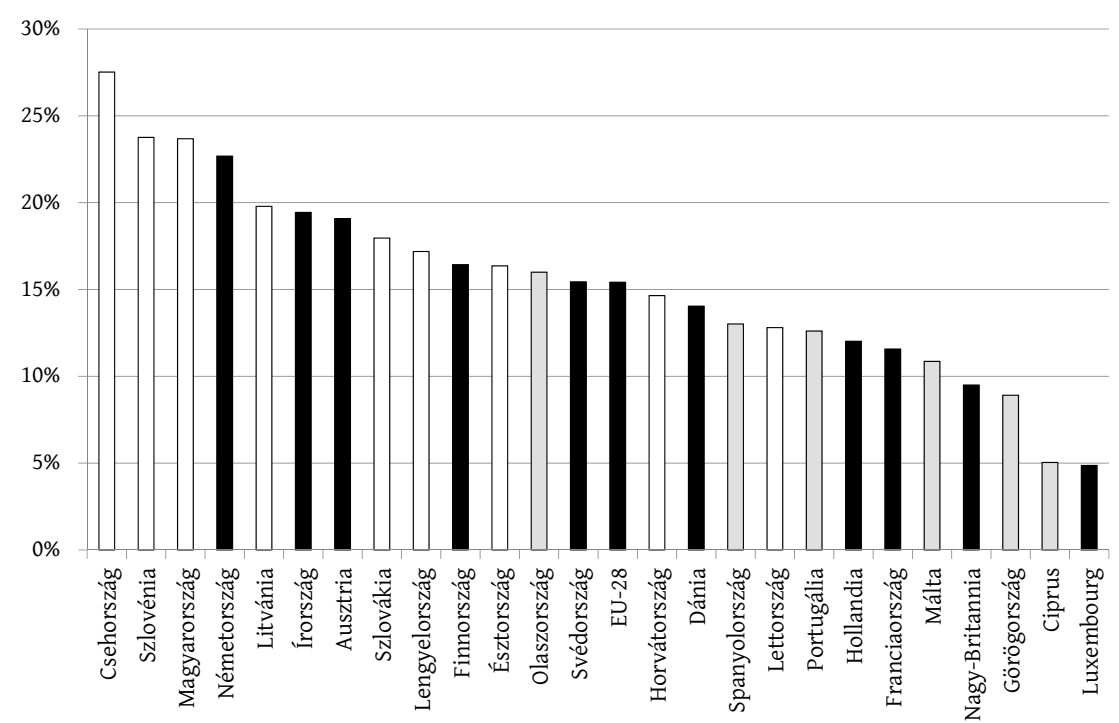

Megjegyzés: A fehér oszlopok a posztszocialista EU-tagállamokat, a fekete oszlopok a régi EU-tagállamokat, a szürke oszlopok pedig a déli periféria országait jelölik. Belgium, Bulgária és Románia vonatkozó adatai nem érhetók el. Forrás: Az Eurostat adatai alapján a szerző szerkesztése. 
Bár a külföldi müködő tőke által vezérelt fejlődési modell sok tekintetben sikeresnek mondható, több ponton fenntartásokkal kell kezelnünk. Egyrészt az ipari integráció elönyei térben rendkívül egyenlötlenül jelentkeznek, és a területi különbségek növekedése tartósnak ígérkezik. Csak a közép-európai régiók aránylag szük köre tekinthető a posztszocialista ipari átalakulás nyertesének, miközben a tőkeáramlások által elkerült ipari térségekben a korábbi ipari bázis leépülését nem követte sem az új, versenyképes iparágak, sem a magas hozzáadott értékü szolgáltatások letelepülése. A kívülről vezérelt (exogén), pozitív útfüggőségen nyugvó fejlődési modellen kívül nem sok látványos sikertörténetről beszélhetünk, a metropolisztérségek sajátos versenyképességi pályája pedig még annyira sem másolható a perifériák számára. Az egyenlőtlen fejlődés komoly tényezővé vált a területi és társadalmi különbségek alakulásában, és nem látszik olyan változás sem, amely enyhülésük felé mutatna.

A transznacionális vállalatok beruházói viselkedése a koncentrált dekoncentráció elvét követi: a globális térben szétterülő hálózatok szubnacionális szinten rendkívül koncentrált telephelyeken jelennek meg; és a jelentős térbeli diszperzió csak az értéklánc alacsony bérszínvonalú, alacsony tudástartalmú szegmenseire jellemző. A technikai szaktudás komplexitása eredendően szürőként viselkedik; a tudásteremtés folyamatai pedig erősen lokalizált, „ragadós” tevékenységek (Iammarino, McCann 2010). Gátat szab a magasabb szegmensek megjelenésének az a probléma is, hogy a globális szétterülés legjobban az érett fejlődési stádiumú iparágakra jellemző, amelyek részegységek alapításával, az értéklánc nemzetközi szétterítésével, valamint termelési hálózatokkal reagálnak az őket ért kihívásokra, s közülük is elsősorban a koncentrált termelésből származó csökkenő hozadékokra (Potter, Watts 2011). A perifériák így nagyon csekély esélyekkel indulnak a nagy léptékü, értékes ipari beruházások megszerzéséért folytatott küzdelemben: ha úgy tetszik, periféria mivoltuk eredendően kizárja őket a potenciális győztesek köréből. Az értékes ipari tevékenységek megszerzésének esélye a beszállítói hálózatokban is alacsony. A K+F- és innovációs tevékenységek korlátozottan megjelennek az „üzemcsarnokon belüli” folyamatinnovációban és inkrementális innovációban, de nem eredményezik a nyugatihoz hasonló nagy léptékü K+F-centrumok letelepülését, mivel a beruházók a vállalati központjaikhoz közel veszik igénybe ezeket a szolgáltatásokat (Pavlínek 2014; Pavlínek, Žižalová 2014; Šipikal, Buček 2013). A periferikus régiók ezen felül egy további dilemmával is szembesülnek: a felzárkóztató szemléletű, szociális célokat szolgáló területfejlesztés érdekei a minél szélesebb foglalkoztatás és a munkaerőpiaci integráció felé mutatnának, a globális verseny és a fenntarthatóság szempontjai viszont a szűkebb, de versenyképesebb ipari tevékenységek felé. Ez az ellentmondás belátható időn belül csak enyhíthetö, de valószínűleg nem oldható fel - miközben a perifériák a szolgáltatásalapú fejlödés kedvező eredményeiből is csak nagyon korlátozottan részesülnek majd.

A külföldi működő tőkén alapú versenyképesség második korlátját a külső tôkefüggőség problémái jelentik, amelyek egyre nagyobb mértékben jelentkeznek a költségalapú versenystratégiák kifulladásával és a versenyképesség „magas 
útját" követő fejlődési utak kialakítására irányuló kísérletekkel. Ez a dilemma nem is tekintheto” „posztszocialista betegségnek”, hiszen számos, összeszerelo tevékenységekre szakosodott nyugat-európai ipari térség már évtizedekkel korábban szembesült azzal, hogy a vállalati telephelyválasztási politikák áldozatává is válhat (Humphrey, Schmitz 2002). A kapitalizmus angolszász („liberális”) és kontinentális („koordinált”) változatától is eltérő függő piacgazdasági modellt (dependent market economies) követő közép-európai gazdaságok azonban nyugati társaiknál sokkal erősebben kitettek a tőkefüggőség kockázatainak (Nölke, Vliegenthart 2009; Pogátsa 2016; Szanyi 2016). Bár a függőség kétirányú, a közép-európai ipari térségek sokkal jobban függnek a nyugati befektetőktől, mint fordítva (a tét nem a kiemelkedő versenyelőnyök elvesztése, hanem egzisztenciális fenyegetés); és míg az előbbiek számára a függés egy egyirányú reláció, az utóbbiaknál csupán egy többirányú viszonyrendszer egyik, mégoly fontos iránya. A külső forrásból táplálkozó, kívülről hozott tudást, technológiákat és forrásokat felhasználó, kívülről irányított iparnak az alábbi lehetséges problémákkal kell szembesülnie:

- A duális közép-európai ipar jelenlegi versenyképességét megalapozó tényezők könnyen válhatnak a jövőbeli feljebb lépési törekvések gátjaivá, és szűkítik az endogén fejlődés felé mutató evolúciós alternatívák feltárásának esélyeit.

- A transznacionális vállalatok, a maguk részéről teljesen logikusan, eltéró viselkedést mutatnak hazai piacaikon és kiszervezett részlegeik esetében. Az értéklánc legértékesebb szegmensei a vállalati központok közelségében maradnak, a periféria termelő kapacitásai pedig kevesebb figyelmet kapnak és könnyebben feláldozhatók. Ennek a viselkedésnek nemzeti eltérései is megfigyelhetők (pl. a német vállalatok magasabb, az amerikai és távol-keleti vállalatok alacsonyabb hajlandósága a magas termelési funkciók letelepítésére). A vállalatokon belüli beruházásokért folyó nemzetközi harc, ha nem is zérus összegü játszma, jelentős érdekkonfliktusokkal jár, és mind rövid, mind hosszú távú vesztesei is vannak.

- Az erős hazai vállalatok hiánya tovagyürüző hatásokat kelt a szolgáltató szektorban is. Csökevényesek maradnak a fejlett üzleti szolgáltatások, mert azokat a vállalatok központjaikhoz közel, az európai és észak-amerikai centrumtérségekben veszik igénybe; elmaradott az alkalmazott kutatások és innovációk rendszere, mivel a telephelyek többségére ilyen tevékenységet nem helyeznek ki; és nem épül ki új, a vállalatoknak kedvező finanszírozási rendszer, mert nincs szervezet, amely rendszeresen igénybe venné őket. ${ }^{12} \mathrm{~A}$ hiányok olyan dimenziókban is megmutatkoznak, amelyeket a közvélekedés nem tart az ipar szerves részének - például az erős nemzeti márkákban (gondoljunk az amúgy nem élvonalbeli olasz ipar itt élvezett előnyeire), a formatervezés és design területén, vagy a marketingben. Ezek a szolgáltatások vagy nem jelennek meg a függő országokban, vagy korlátozottak maradnak. 
- Számottevő közép- és hosszú távú kockázat származik a tókemozgásokból. A transznacionális vállalatok részlegei nagyon erős versenyt folytatnak a profit újbóli befektetéseért, és a vállalati központok stratégiái könnyen dönthetnek annak repatriálásáról vagy máshol történő felhasználásáról. A költségelőnyök csökkenése kilépésre ösztönözheti az alacsony tényezőintenzitású termelésre szakosodott vállalatokat, iparágakat (pl. a könnyűipar vagy - az elmúlt években jól látható módon - az elektronikai ipar szereplőit).

- A sikeres ipari térségeket is fenyegetik a kiszoritó és eltömődési hatások, amelyek visszafogják a további tőkebefektetések hatékonyságát, és a képzett munkaerő elszívásával, a helyi piacok lefölözésével a térségi kisés középvállalati szektor további háttérbe szorulását és a meglévő helyi ipari hálózatok felbomlását eredményezhetik.

- A függő modell legfontosabb mellékhatásaként a külső tőkeberuházásokra alapozott modellben alacsony a pénzügyi, humán és társadalmi tóke akkumulációja. A liberális és koordinált piacgazdaságokkal szemben a függő piacgazdaságok történelmi tőkehiánya újratermeli magát; különösen az időről időre bekövetkező, a gyakori rendszerváltásokkal járó transzformációs veszteségeknek (Gál 2013) köszönhetően. A vállalatokban megtermelt profit a munkabéreken és beszedett adókon keresztül fontos multiplikátor-hatásokat generál (bár a befektetésvonzó politikák révén könnyen jutnak olyan versenyelőnyökhöz, közterheik ideiglenes vagy tartós csökkentéséhez, amelyekről egyszerü halandók nem is álmodhatnak), de a legfontosabb eredmény, a tőkeképződés és az új vállalatok térségi megújulást elősegítő kialakulása elmaradhat.

- Az alacsonyan tartott bérszínvonal ösztönzi a jobb jövedelmi viszonyokat és életkörülményeket kínáló hazai és európai centrumtérségek felé irányuló tartós migrációs folyamatokat, amelyek aláaknázzák egyes térségek vagy teljes nemzetgazdaságok humántőke-akkumulációját is.

Nyilvánvaló, hogy a fenti problémák kialakulása nem egyedül a külső tőkebefektetők felelőssége, és orvoslásuk sem várható el tőlük. Ugyanakkor belátható, hogy a függő piacgazdasági modell nagymértékben hozzájárul a közepes jövedelmü fejlődés csapdájának (middle income trap) kialakulásához, s még ezen felül is súlyos fenntarthatósági dilemmák terhelik. A függőség rendszerei önmagukban ördögi kört formálnak, amelyből különösen nehéz kitörni. A vállalatok és ipari térségek ugyanis könnyen olyan fejlődési pályákra kényszerülhetnek, amelyek vagy nem képesek biztosítani a versenyképesség magas útja felé való elmozdulást, vagy fenntarthatatlanoknak bizonyulhatnak.

Harmadikként említést kell tennem a feljebb lépés és endogén növekedés lehetöségeit, pontosabban a tudásalapú gazdaság meghonosodását hátráltató korlátokról is. A korábban már említett térségi hálózatok fejletlensége mellett ugyanis legalább ilyen gyenge lábakon áll a tudáshálózatok fejlettsége, a kollektív tanulás és az innovációs rendszerek teljesítőképessége. Ezen a téren Közép- és Délkelet- 
Európában csak Szlovénia adottságai érik el a megfelelő színvonalat. A térség fennmaradó részét, különösen a délkeleti országok csoportját vizsgálva a kép lényegesen kedvezőtlenebb: nem csupán az innovatív, tudásintenzív ipar, hanem a tudásalapú gazdaság alapvető feltételrendszere is elmaradásokkal küzd. A Világbank által készített, a tudásgazdaságra való felkészültséget vizsgáló potenciálfelmérés adatai alapján szembetűnő, hogy mind a tudás hasznosításában elért teljesítmény (tudásgazdasági index), mind a potenciálisan felhasználható tudás (tudásindex), mind pedig ezek részindexei - az innovációpolitika ösztönzői és intézményei, az oktatás és emberi erőforrások teljesítménye, az infokommunikációs technológiák elterjedtsége - jelentős lemaradást mutatnak (World Bank 2012). A délkeleti országok csoportjában egyedül az infokommunikációs ellátottság volt aránylag kedvező; lemaradásuk átlagosan kétszer akkora volt a visegrádi országok és Szlovénia alkotta csoporthoz képest, mint azoké az EU 15ökhöz. A posztszocialista átalakulás paradoxona, hogy pont azokban az évtizedekben, amikor világszerte egyre erősebb bizonyítékok állnak rendelkezésre a tudás gazdasági fejlődésben játszott szerepének jelentőségéről, a makrorégió országai a fünyírószerű fiskális megszorítások prédájaként kezelték a társadalmi fejlődés két alappillérét, a közoktatást és az egészségügyet.

\section{Következtetések a fenntartható iparfejlődésről}

Huszonöt év hosszú idő, és elég ahhoz, hogy a lezajlott átalakulási folyamatok következményeit már ne egy átmeneti időszak termékeinek, hanem tartós fejlődési jegyeknek tartsuk. Könnyen belátható, hogy az ipar térformáló szerepe, a gazdasági növekedésre és egyes régiók, térségek foglalkoztatására gyakorolt hatása miatt nem hagyható figyelmen kívül a válság utáni Közép-Európában sem. Az iparfejlődést azonban térben differenciált folyamatként kell értelmeznünk mind az empirikus elemzésekben, mind a fejlesztéspolitikában. Miközben a metropolisztérségek, központi régiók számára követhető útnak tűnik egy döntően szolgáltatásalapú fejlődési pálya (egyes innovatív iparágak és az iparhoz kapcsolódó fejlett üzleti szolgáltatások kitüntetett szerepével), az ipari átalakulás nyerteseivé váló átmeneti régiókban és a kiüresedő periferikus régiók felzárkóztatásában a posztindusztriális gazdaság nem jelenthet ipar nélküli fejlődést; kiegyensúlyozott gazdaságszerkezet megteremtésére van szükség, ennek érdekében pedig az ipari és szolgáltató tevékenységek kombinációira alapozott stratégiákat érdemes követni. Ezekben a kombinációkban növekvő jelentőségre tesznek szert az erősen lokalizált versenyképességi tényezők, amelyek egyben a térségi (újra)specializáció, a hálózatokra alapozott endogén fejlődés építőkövei.

A specializáció elsősorban nem egyes vállalatokat kell, hogy jelentsen, hanem átalakítható, újabb és újabb fejlesztési célokra és ipari tevékenységekre fókuszálható, átállítható rugalmas tudáskészletet és szervezeti rendszert. A közelmúltban 
a visegrádi országokban már jelentkeztek a túlzott autóipari szakosodás kedvezőtlen mellékhatásai (pl. az autóipari ciklus megjelenése a magyar GDP-adatok hullámzásában), illetve fel kell készülni rá, hogy egyetlen iparág ilyen mértékű uralma kiszolgáltat a külső sokkoknak, és a régi ipari térségekhez hasonló hálózati-agglomerációs problémák kialakulását eredményezheti. Ebben és a hasonló esetekben a generikus ipari tudás szerepét érdemes hangsúlyozni: az autóipar konverziója pl. számos új gépipari tevékenység meggyökerezéséhez vezethet, míg az elmúlt évtizedben egyre inkább meggyengülő elektronikai összeszerelő tevékenységek kiváltására az infokommunikációs tevékenységek és a szoftveripar tünnek a legalkalmasabbaknak.

A következő évtizedekben nincs realitása a külföldi müködö tőke és know-how széles körü kiváltásának, de a fejlődési modell gyengeségeit orvosolni szükséges. A külföldi működő tőkén alapuló fejlődés első másfél évtizedének látványos sikerei nem a semmiben gyökereztek, és a fejlődés kiugró üteme nem volt fenntartható. Ebben az időszakban ugyanis nagyrészt az a látens ipari potenciál alakult újjá, amelyet a szocialista nagyvállalatok, termelési rendszerek felbomlása szabadított fel, és a külföldi beruházók foglaltak új rendszerbe - a saját érdekeik és elképzeléseik szerint. Nyilvánvaló, hogy ez a sors sokkal kedvezőbb volt, mint azon ipari térségeké, ahol az egykori ipari bázis nyom nélkül vagy csak néhány utódvállalatot maga mögött hagyva tűnt el, és nagy vonalakban - bár nem minden esetben - egyetérthetünk Szanyi (2016) azon érvelésével, hogy még az elönyök és hátrányok egyenlőtlen megosztásával járó globális piaci integráció is jobb alternatíva, mint az abból való kimaradás. Mindez azonban nem mentesít a külső tökefüggés mérséklésének feladatai alól.

A közép-európai országok jelenlegi kiszolgáltatottsága elsősorban két úton mérsékelhető. Egyrészt erősíteni kell a külföldi működő tőkén alapuló ipari tevékenységek területi beágyazottságát, és elősegíteni az értékes ipari funkciók megtelepedéséhez vezető iparági feljebb lépést. Másrészt a korábbinál sokkal több figyelmet kell szentelni a vállalati ökoszisztéma külföldi nagyberuházók melletti szereplőire is. Hiányzik a nemzeti bajnok vállalatok köre, pedig ezek nemcsak a keletázsiai fejlesztő államok felzárkózásában, hanem a ma fejlett európai országok iparfejlődésében is kulcsszerepet játszottak. Nincs annak realitása, hogy a rendszerváltásokkal elveszett nagyvállalatok feltámaszthatók vagy egykönnyen újakkal pótolhatók lennének, de amelyek fennmaradtak, ott aktív állami segítséggel érdemes támogatni a hazai beszállító rendszerek felépülését; másrészt az elérhető iparpolitikai eszközök maximális kihasználásával ösztönözni azt, hogy a sikeres kisvállalatok versenyképes középvállalatokká fejlődjenek, a közepesek pedig versenyben maradva a német modellhez hasonló többgenerációs cégekké fejlődjenek. A Magyarországon az elmúlt években (nem csak az iparban) megfigyelhető gyakori kilépési stratégiák, a versenyképes piaci szereplőkké kinövő hazai vállalatok külföldi befektetői csoportok kezébe adása súlyos figyelmeztetés a gazdaságpolitika alakítóinak, és komoly növekedési korlátokra utal; de a probléma tükörképei a többi közép-európai országban is minduntalan feltűnnek. 
Akár a külföldi tőkén alapuló vállalkozások értékes tevékenységeinek megszerzése a cél, akár a hazai ipar megerősítése, az iparfejlődés fenntartható fejlődésének legfontosabb záloga azonban a tényezőellátottság tartós javitása. Ez a tőkefinanszírozás lehetőségeinek javítását, a megfelelő munkaellátottságot, a szabályozási, adóztatási környezet javítását is szükségessé teszi, kulcstényezője azonban a tudásalapú társadalom fö erőforrása, a humán tőke lesz. Az állami politikák legjobban megtérülő beruházása a képzés, elsősorban a szakképzett munkaerő Közép-Európa-szerte egyre nagyobb problémákat jelentő hiányának csökkentésével. Ez a probléma mindkét fő fejlődési útnál felmerül, orvoslása tehát kiemelkedő nemzetgazdasági érdek. A magas képzettséggel és az alkalmazkodás, élethosszig tartó tanulás képességével felvértezett szakemberek széles rétege már ma is stratégiai kérdés és az ipartelepítési döntések egyik fö kritériuma, de teljes jelentőségét a következő évtizedekben nyeri el. Az alacsony képzettségi szintet igénylő vagy betanított munka egyre növekvő hányadának gépesítése mellett ez a fajta ipari munka a belátható jövőben is keresett marad, és széles rétegek számára kedvező bérszínvonal elérését teszi lehetővé.

\section{Köszönetnyilvánítás}

A tanulmány elkészítését az NKFIH NK 104985 számú kutatása („Új térformáló erők és fejlődési pályák Kelet-Európában a 21. század elején") és a Bolyai János Kutatási Ösztöndíj támogatta. A szerző köszönettel tartozik a tanulmány két anonim lektorának, akik javaslataikkal és bírálataikkal segítették a kézirat átdolgozását. A fennmaradó tévedések a szerzőt terhelik.

\section{Jegyzetek}

1 Jelen tanulmány elsősorban a visegrádi négyekkel, másodsorban Szlovéniával, harmadrészt Romániával, Bulgáriával, valamint Jugoszlávia utódállamaival foglalkozik. A következtetések többsége mindhárom országcsoportra érvényes, de - a külföldi működőtőke-beruházások eltérő szintje és befolyása révén - más-más mértékben. A fó különbségeket a tanulmány külön tárgyalja.

2 Más megközelítésből kiindulva, de hasonló térfelosztást rajzolnak ki Kuttor (2010), Kuttor és Hegyi-Kéri (2012), valamint Lengyel (2012) tanulmányai.

3 Az összehasonlíthatóság érdekében Csehország, Románia és Szlovákia esetében összevontam a fövárosok és környezetük adatait.

4 Valamelyest eltérő szemléletet képvisel Szabó és Farkas (2014), akik a modern ipar csomópontokba koncentrált szerveződése mellett érvelnek - álláspontjuk szerint térségünkben a hagyományos bányászati-ipari körzetek meggyengülését követően az ipar nem képez összefüggő térszerkezeti elemeket (tengelyeket vagy zónákat).

5 A delokalizáció (áttelepítés) helyett helyesebb iparvállalatok, iparágak utódlás nélküli eltűnéséről, destruktív dezindusztrializációs jelenségekről beszélni.

6 A győri iparági körzet történelmi gyökereiről lásd egy nemrég megjelent tanulmánykötet rendkívül gazdag anyagát (Germuska, Honvári 2014; Honvári 2014; Jakab 2014), valamint Rechnitzer (2016) 
monográfiáját. A történelmi minták Kecskemét autóipara esetében is kimutathatók. A Mercedes letelepülését jóval megelőzte az 1964-ben létrehozott Gépipari és Automatizálási Műszaki Főiskola, az 1962-től működő Pneumatikus és Hidraulikus Gépelemek Gyára, a gyár Knorr-Bremsével kötött 1972-es licenszmegállapodása, majd 1989-es vegyesvállalattá alakítása, privatizációja. A város tehát komoly gépgyártási hagyományokra támaszkodhatott, amikor a beruházási döntést meghozták.

7 Lásd pl. a kívülről irányított délolasz modernizáció példáját a helyi gazdaságba beilleszkedni képtelen nagyiparral („sivatagi katedrálisok”: Dunford, Greco 2007; Greco, DiFabbio 2014; Horváth 1998), vagy a földrajzi nihilizmusból kiinduló, s a területi szempontokat később is háttérbe szorító államszocialista iparosítás súlyosan diszfunkcionális területi következményeit (Lux 2016). A probléma természetesen nem szükíthető le a múltra: Lovering (1999) az új területi politikák kapcsán megfogalmazott kritikája ma is érvényes.

8 Magyarországon erre Győr szolgáltatja a legjobban feltárt és a köztudatban legélénkebben élő példát (Rechnitzer 2016), de a következtetések jól alkalmazhatók a közép-európai feldolgozóipari integrációs zónába sikeresen beilleszkedő ipari térségek zömére.

9 A probléma a fejlett országok periferikus térségeiben is ismert (Kasabov 2011; Nuur, Laestadius, 2010).

10 A lekérdezés során 540 angol nyelvủ kérdőívet juttattunk el közép-európai országok kiválasztott területfejlesztési szereplőihez. A visszaérkezett 154 kérdőív válaszadási rátája 18\%. A válaszok 33\%-a egyetemekről, 31\%-a fejlesztő szervezetektől, 16\%-a területi statisztikai ügynökségektől, 20\%-a pedig városi önkormányzatoktól érkezett. A fövárosok aránya $17 \%$, a vidéki válaszoké $83 \%$ volt. A válaszok országos bontása: 30\% Lengyelország, 19\% Csehország, 15\% Magyarország, $10 \%$ Bulgária, míg a fennmaradó országok aránya egyenként $10 \%$ alatt maradt.

11 Mint Jürgens és Krzywdzinski (2009) bemutatja, a nyugati beruházók óvakodtak attól, hogy a szociális partnerség intézményeit meghonosítsák Közép-Európában; ugyanakkor a képzett szakmunkások állásai formális garanciák hiányában is aránylag biztonságosaknak számítanak a fokozatosan kibontakozó munkaerőhiány körülményei között. Hozzátehetjük, hogy a hazai tulajdonú vállalatok még ennyire sem nyitottak a munkavállalók érdekérvényesítésére; a szakszervezetekhez való viszonyulásuk többnyire nyíltan ellenséges.

12 A magas külföldi tulajdonhányadú bankszektor eredendően nem mutatott magas hajlandóságot a kiterjedt vállalkozói hitelezésre. A zömmel hazai tulajdonú szlovén bankok esetében a helyzet kedvezőbb, bár a probléma ott is létezik (Mörec, Raškovic 2011).

\section{Irodalom}

Anić, I. D., Rajh, E., Teodorović, I. (2008): Full manufacturing versus subcontracting business models in the Croatian textile and clothing industry. Economic Review/Ekonomski Pregled, 7-8., 325-343.

Bailey, D., DePropris, L. (2014): Manufacturing reshoring and its limits: The UK automotive case. Cambridge Journal of Regions, Economy and Society, 7., 379-395. http://doi.org/bxtb

Baranyai, N., Lux, G. (2014): Upper Silesia: The revival of a traditional industrial region in Poland. Regional Statistics, 2., 126-144. http://doi.org/br56

Barta Gy. (2000): A külföldi működő tőke szerepe a magyar ipar duális struktúrájának kialakulásában. In: Horváth Gy., Rechnitzer J. (szerk.): Magyarország területi szerkezete és folyamatai az ezredfordulón. MTA Regionális Kutatások Központja, Pécs, 275-292.

Barta, Gy. (2005): The role of foreign direct investment in the spatial restructuring of Hungarian industry. In: Barta, Gy., G. Fekete, É., Szörényiné Kukorelli, I., Timár, J. (eds.): Hungarian spaces and places: patterns of transition. Centre for Regional Studies, Pécs, 143-160.

Barta Gy., Czirfusz M., Kukely Gy. (2008): Újraiparosodás a nagyvilágban és Magyarországon. Tér és Társadalom, 4., 1-20.

Barta, Gy., Lőcsei, H. (2011): The effect of the recent economic crisis on the spatial structure of Hungarian industry. Regional Statistics, 1., 99-109. 
Bell, D. (1973): The coming of post-industrial society: A venture in social forecasting. 1999 special anniversary edition. Basic Books, New York

Competing in global value chains: EU industrial structure report 2013 (2013). European Commission Directorate-General for Enterprise and Industry, Luxembourg

Csomós Gy. (2011): A közép-európai régió nagyvárosainak gazdaságirányító szerepe. Tér és Társadalom, 3., 129-140.

Drobniak, A., Kolka, M., Skowroński, M. (2012): Transition and urban economic resilience in Poland's post-industrial cities: The case of Katowice. Regions, 286., 13-15.

Dunford, M., Greco, L. (2007): Geographies of growth, decline and restructuring. The rise and fall (privatization) of the state-owned steel sector and the trajectories of steel localities in the Italian Mezzogiorno. European Urban and Regional Studies, 1., 27-53. http://doi.org/dgtk8r

Egyed I. (2014): Területfejlesztés vagy iparpolitika? A francia versenyképességi pólus program tapasztalatai. Tér és Társadalom, 2., 159-175.

Enyedi Gy. (1978): Kelet-Közép-Európa gazdaságföldrajza. Közgazdasági és Jogi Könyvkiadó, Budapest

Evgeniev, E. (2008): Industrial and firm upgrading in the European periphery. The textile and clothing industry in Turkey and Bulgaria. Professor Marin Drinov Academic Publishing House, Sofia

Faragó L., Lux G. (2014): Kurrens portéka vagy múzeumi tárgy? Növekedési pólusok és iparági körzetek a fejlesztéspolitikában, Tér és Társadalom, 2., 11-30.

For a European industrial renaissance. (2014) European Commission, Brussels

Frigant, V., Layan, J. B. (2009): Modular production and the new division of labour within Europe. The perspective of French automotive parts suppliers. European Urban and Regional Studies, 1., 11-25. http://doi.org/cz7knv

Gál, Z. (2013): Role of financial sector FDI in regional imbalances in Central and Eastern Europe. Gostyńska, A., Tokarski, P., Toporowski, P., Wnukowski, D. (eds.): Eurozone enlargement: Challenges for the V4 countries. The Polish Institute of International Affairs, Warsaw, 27-35.

Germuska P., Honvári J. (2014): A közúti jármügyártás története Győrött 1945-től 1990-ig. In: Honvári J. (szerk.): Győr fejlődésének mozgatórugói. Universitas-Győr Nonprofit Kft., Győr, 21-111.

Greco, L., DiFabbio, M. (2014): Path-dependence and change in an old industrial area: The case of Taranto, Italy. Cambridge Journal of Regions, Economy and Society, 7., 413-431. http://doi.org/bxtc

Gwosdz, K. (2014): Pomiędzy starą a nową ścieżką rozwojową. Mechanizmy ewolucji struktury gospodarczej i przestrzennej regionu tradycyjnego przemysłu na przykładzie konurbacji katowickiej po 1989 roku. Uniwersytet Jagelloński w Krakowie, Instytut Geografii i Gospodarki Przestrzennej, Kraków

Harrison, B. (1992): Industrial districts: Old wine in new bottles? Regional Studies, 5., 469-483. http://doi.org/fm2mzc

Havlik, P. (2005): Central and East European industry in an enlarged European Union: Restructuring, specialisation and catching-up. Économie Internationale, 102., 107-132.

Honvári J. (2014): Bevezető. In: Honvári J. (szerk.): Győr fejlődésének mozgatórugói. Universitas-Győr Nonprofit Kft., Győr, 7-19.

Horváth Gy. (1998): Európai regionális politika. Dialóg Campus Kiadó, Budapest, Pécs

Humphrey, J., Schmitz, H. (2002): How does insertion in global value chains affect upgrading in industrial clusters? Regional Studies, 9., 1017-1027. http://doi.org/cjfq7r

Iammarino, S., McCann, P. (2010): The relationship between multinational firms and innovative clusters. In: Boschma, R., Martin, R. (eds.): The handbook of evolutionary economic geography. Edward Elgar, Cheltenham, 182-204. http://doi.org/bxtd

Jakab P. (2014): Sikeres gazdasági modellváltások Győrben. In: Honvári J. (szerk.): Győr fejlődésének mozgatórugói. Universitas-Győr Nonprofit Kft., Győr, 140-157.

Jürgens, U., Krzywdzinski, M. (2009): Changing East-West division of labour in the European automotive industry. European Urban and Regional Studies, 1., 27-42. http://doi.org/cc2qsw

Kaditi, E. A. (2013): Foreign investments and institutional convergence in South-Eastern Europe. International Economic Journal, 1., 109-126. http://doi.org/bxtf

Kasabov, E. (2011): Towards a theory of peripheral, early-stage clusters. Regional Studies, 6., 827-842. http://doi.org/b32ng5

Kiss, É. (2007a): Foreign direct investment in Hungary. Industry and its spatial effects. Eastern European Economics, 1., 6-28. http://doi.org/d6nmpg 
Kiss, É. (2007b): The impacts of relocation on the spatial pattern to Hungarian industry. Geographia Polonica, 1., 43-61.

Kornai J. (1980): A hiány. Közgazdasági és Jogi Könyvkiadó, Budapest

Kovács T. (2003): Vidékfejlesztési politika. Dialóg Campus Kiadó, Budapest, Pécs

Krzywdzinski, M. (2014): How the EU's eastern enlargement changed the German productive model. The case of the automotive industry. Revue de la Régulation, 1., 1-20.

Kuttor D. (2010): A gazdasági-politikai átmenet regionális hatásainak vizsgálata a visegrádi országokban 1995-től 2006-ig. Tér és Társadalom, 4., 249-265.

Kuttor, D., Hegyi-Kéri, Á. (2012): Sectoral and regional dimensions of industrialisation in East Central Europe. In: Pavelkova, D., Strouhal, J., Passekova, M., Sucháček, J. (eds.): Advances in economics, risk management, political and law science. WSEAS Press, Zlin, 290-299.

Lefilleur, J. (2008): Geographic reorganisation of the European automobile sector. What role for the Central and East European countries in an enlarged European Union? An empirical approach. Eastern European Economics, 5., 69-91. http://doi.org/dx4wrz

Lengyel I. (2010): Regionális gazdaságfejlesztés. Versenyképesség, klaszterek és alulról szerveződo” stratégiák. Akadémiai Kiadó, Budapest

Lengyel I. (2012): A hazai területfejlesztés zsákutcái: A triális Magyarország. In: Rechnitzer J., Rácz Sz. (szerk.): Dialógus a regionális tudományról. Széchenyi Egyetem Regionális- és Gazdaságtudományi Doktori Iskola, Magyar Regionális Tudományi Társaság, Gy̋̋r, 140-150.

Lengyel, I. (2014): Reorganization of Hungarian manufacturing sector: Impacts of EU accession and global crisis. European Journal of Business Research, 2., 93-100. http://doi.org/bxtg

Lengyel I., Szakálné Kanó I., Vas Zs., Lengyel B. (2016): Az újraiparosodás térbeli kérdőjelei Magyarországon. Közgazdasági Szemle, 6., 615-646. http://doi.org/bxth

Lovering, J. (1999): Theory led by policy: The inadequacies of the 'new regionalism' (illustrated from the case of Wales). International Journal of Urban and Regional Research, 2., 379-395. http://doi.org/dn6hfd

Lux G. (2013): Kritikus tömeg alatt: A fejlesztési együttműködés lehetőségei a kisebb nagyvárosokban, Tér és Társadalom, 4., 52-74.

Lux G. (2016): Az államszocialista iparpolitika területi következményei. In: Erdős K., Komlósi É. (szerk.): Tanitványaimban élek tovább: Emlékkötet Buday-Sántha Attila tiszteletére. Pécsi Tudományegyetem Közgazdaságtudományi Kar, Pécs, 89-105.

Menzel, M. P., Fornahl, D. (2009): Cluster life cycles - Dimensions and rationales of cluster evolution. Industrial and Corporate Change, 1., 205-238.

Miles, I. (1993): Services in the new industrial economy. Futures, 6., 653-672. http://doi.org/bdvsgr

Molnár E. (2010): Közép- és Délkelet-Európa határán: Gazdasági modernizáció és szerkezetváltás Romániában. In: Demeter G., Radics Zs. (szerk.): Kompországok - ahol a part szakad... Szemelvények Köztes-Európa integrációs törekvéseiből (1990-2008). Didakt Kiadó, Debrecen, 370-411.

Molnár E. (2012): Kelet-Közép-Európa az autóipar nemzetközi munkamegosztásában. Tér és Társadalom, 1., 123-137.

Molnár E., Lengyel I. M. (2015): Újraiparosodás és útfüggőség: Gondolatok a magyarországi ipar területi dinamikája kapcsán. Tér és Társadalom, 4., 42-59. http://doi.org/bxtj

Monastiriotis, V., Alegria, R. (2011): Origin of FDI and intra-industry domestic spillovers: The case of Greek and European FDI in Bulgaria. Review of Development Economics, 2., 326-339. http://doi.org/bw5z6g

Mörec, B., Rašković, M. (2011): Overview and estimation of the 2008 financial and economic crisis 'effect size' on SME capital structures: Case of Slovenia. Ekonomska Istraživanja, 4., 107-125. http://doi.org/bxtk

Nölke, A., Vliegenthart, A. (2009): Enlarging the varieties of capitalism: The emergence of dependent market economies in East Central Europe. World Politics, 4., 670-702. http://doi.org/b54rvf

Nuur, C., Laestadius, S. (2010): Development in peripheral regions: Case studies in Sweden. European Urban and Regional Studies, 3., 293-307. http://doi.org/c2xzxc

Páger B. (2013): Ismét az „ígéret földje”? Łódz gazdasági átalakulása a rendszerváltást követően. In: Rechnitzer J., Somlyódyné Pfeil E., Kovács G. (szerk.): A hely szelleme - a területi fejlesztések lokális dimenziói: A Fiatal Regionalisták VIII. Konferenciáján elhangzott elöadások. Széchenyi István Egyetem Regionális- és Gazdaságtudományi Doktori Iskola, Győr, 447-458.

Pástor, R., Šipikal, M., Rehák, Š. (2013): Knowledge creation and knowledge acquisition in the software 
industry in Slovakia: The case study of Košice region. Regional Science Policy \& Practice, 4., 401-415. http://doi.org/bxtm

Pavlínek, P. (2012): The internationalization of corporate R\&D and the automotive industry R\&D of East-Central Europe. Economic Geography, 3., 279-310. http://doi.org/bxtn

Pavlínek, P. (2014): Whose success? The state-foreign capital nexus and the development of the automotive industry in Slovakia. European Urban and Regional Studies. 1-23. http://doi.org/bxtp

Pavlínek, P., Domański, B., Guzik, R. (2009): Industrial upgrading through foreign direct investment in Central European automotive manufacturing. European Urban and Regional Studies, 1., 43-63. http://doi.org/dvq2q6

Pavlínek, P., Ženka, J. (2010): The 2008-2009 automotive industry crisis and regional unemployment in Central Europe. Cambridge Journal of Regions, Economy and Society, 3., 349-365. http://doi.org/bw6jj8

Pavlínek, P., Žižalová, P. (2014): Linkages and spillovers in global production networks: Firm-level analysis of the Czech automotive industry. Journal of Economic Geography, 1 - 33. http://doi.org/bxtq

Petrakos, G., Totev, S. (2000): Economic structure and change in the Balkan region: Implications for integration, transition and economic cooperation. International Journal of Urban and Regional Research, 1., 95-113. http://doi.org/b85vc3

Pogátsa Z. (2016): Magyarország politikai gazdaságtana: Az északi modell esélyei. Osiris, Budapest

Potter, A., Watts, D. (2011): Evolutionary agglomeration theory: Increasing returns, diminishing returns, and the industry life cycle. Journal of Economic Geography, 11., 417-455. http://doi.org/cj7xkc

Rechnitzer J. (2016): A területi tóke a városfejlődésben: A Győr-kód. Dialóg Campus Kiadó, Budapest, Pécs

Rugraff, E. (2008): Are the FDI policies of the Central European countries efficient? Post-Communist Economies, 3., 303-316. http://doi.org/dpzwk4

Šipikal, M., Buček, M. (2013): The role of FDIs in regional innovation: Evidence from the automotive industry in Western Slovakia. Regional Science Policy \& Practice, 4., 475-491. http://doi.org/bxtr

A stronger European industry for growth and economic recovery. Industrial policy communication update (2012). European Commission DG Enterprise and Industry, Brussels

Sucháček, J., Krpcová, M., Stachoňová, M., Holešinská, L., Adamovský, J. (2012): Transition and resilience in Czech post-industrial towns: The case of Ostrava and Karviná. Regions, 286., 17-19.

Szabó P., Farkas M. (2014): Kelet-Közép-Európa térszerkezeti képe. Tér és Társadalom, 2., 67-86.

Szanyi, M. (2016): The FDI-led development model revisited? The case of Hungary. CERS HAS Institute of World Economics, Budapest (Working Paper; 220.)

Totev, S. (2005): Foreign Direct Investment in Bulgaria: Advantages and disadvantages to investment. South-East Europe Review, 4., 91-104.

Winiecki, J. (1986): Az ipar túlméretezettsége a kelet-európai szocialista országokban: tények, okok, következmények. Közgazdasági Szemle, 5., 579-592.

Wójtowicz, M., Rachwał, T. (2014): Globalization and new centers of automotive manufacturing: The case of Brazil, Mexico, and Central Europe. Prace Komisji Geografii Przemystu, 25., 81-107.

World Bank Knowledge Assessment Methodology (2012). http://web.worldbank.org

Yoruk, D. E. (2004): Patterns of industrial upgrading in the clothing industry in Poland and Romania. In: McGowan, F., Radosevic, S., von Tunzelman, N. (eds.): The emerging industrial structure of the wider Europe. Routledge, London, New York, 95-110. http://doi.org/dxw5mh 